\title{
Learning for resilience in the European Court of Human Rights: adjudication as an adaptive governance practice
}

\author{
Simon P. West ${ }^{1}$ and Lisen Schultz ${ }^{1}$
}

\begin{abstract}
Managing for social-ecological resilience requires ongoing learning. In the context of nonlinear dynamics, surprise, and uncertainty, resilience scholars have proposed adaptive management, in which policies and management actions are treated as experiments, as one way of encouraging learning. However, the implementation of adaptive management has been problematic. The legal system has been identified as an impediment to adaptive management, with its apparent prioritization of certainty over flexibility, emphasis on checks and balances, protection of individual rights over public interests, and its search for "transcendent justice" over "contingent truth." However, although adaptive management may encourage learning for ecological resilience, it is only one aspect of the institutional change needed to foster learning for social-ecological resilience. The mechanisms, including law, that provide for pursuit and protection of evolving ideas of justice and equity are critical for guiding human understanding of and interaction with the material environment. A broader agenda for learning within and about social-ecological resilience that focuses on the interaction between ideas of justice and equity with ecosystem dynamics is captured in the concept of adaptive governance. We have built on recent literature that has elaborated on the role of law in governance of social-ecological systems by analyzing environmental cases in the European Court of Human Rights (ECtHR). We find that the ECtHR contributes to adaptive governance by supporting multiple ways of knowing the environment, enhancing polycentricity, and encouraging adaptive management and policy making by member states in the context of public participation. We have argued that the environmental case law of the ECtHR constitutes an important site of learning for governance of social-ecological systems, because it situates knowledge and experience of environmental change in the context of discussions about the relative rights, duties, and responsibilities of social actors, facilitating the mutually adaptive evolution of truth and justice across scales.
\end{abstract}

Key Words: adaptive governance; law; learning; resilience; rights

\section{INTRODUCTION}

Learning is a central component of resilience, in terms of both driving system change and enabling more effective responses to change. In a complex world of surprise, uncertainty, and nonlinearity, resilience scholars have proposed adaptive management based on experimentation, monitoring, and knowledge exchange to enable continual learning about ecosystems (Holling 1978, Walters 1986). Intuitively, this vision of adaptation and experimentation seems to contradict the role of law "to provide concepts, rules, procedures, and institutions ... to protect certain societal values such as equality before the law and non-discrimination" (Ebbesson and Hey 2013). Consequently, resilience scholars have formed an ambivalent relationship to the law. For instance, the restrictions placed on adaptive ecosystem management by administrative law in the United States have produced a critique of law as concerned with "transcendent justice" at the expense of "contingent truth" and with creating certainty over flexibility (Cosens 2008, Holling 2012, Arnold and Gunderson 2013). Walker (2012) exemplifies this critique, suggesting that law is the primary source of declining resilience in the Western world.

However, although adaptive management may enhance learning for ecological resilience, it is only one of the institutional changes needed to foster learning for social-ecological resilience (Cosens and Williams 2012). Carpenter et al. (2001) define socialecological resilience in terms of (1) the degree of disturbance a system can absorb, (2) the degree to which the system is capable of self-organization, and (3) the degree to which the system can build and increase the capacity of learning and adaptation. Realization of these qualities in a social-ecological system emerges through the interaction of ecological processes and functions with institutional forms and structures and with the discursive dynamics driving competing forms of environmental value creation (Folke 2006, Leach et al. 2010). Learning for socialecological resilience therefore emerges through reflection on the interaction, articulation, and contestation of material, social, and discursive dynamics across scales (Lundholm and Plummer 2010). The complex institutional changes implied by this expansion of learning for resilience are captured in the concept of adaptive governance (Folke et al. 2005, Olsson et al. 2006, Huitema et al. 2009, Chaffin et al. 2014).

Adaptive governance refers to the institutional and social contexts through which adaptive management may emerge (Folke et al. 2005). The concept of learning expands beyond experimentation and monitoring to include knowledge sharing between multiple actors at different scales of decision making (Cundill et al. 2015). Key aspects of adaptive governance include cross-scale connections between formal institutions, informal groups or networks, bridging organizations, and individuals (Folke et al. 2005); the integration of multiple "ways of knowing" the environment, including scientific, local, traditional, and experiential knowledge (Hahn et al. 2006); polycentric systems (Olsson et al. 2006, Ostrom 2010); and opportunities for public participation (Huitema et al. 2009). However, although adaptive governance provides for a broader conceptualization of learning to account for social-ecological as opposed to merely ecological 
resilience, the literature has paid less attention to the ways in which divergent knowledge, values, and interests among social actors produce plural and contingent framings of social-ecological systems (Leach et al. 2010). Therefore, adaptive governance is increasingly combined with reflexive (Voß et al. 2006) and deliberative principles (Dryzek 2000, Hajer and Wagenaar 2003). When adaptive governance prescriptions are interpreted in terms of the reflexive emphasis on diverse, evolving knowledge and the contingency of social goals, and the deliberative insistence on dialogue and negotiation, then adaptive governance forms the arena in which the goals, or "ends," of adaptive management are negotiated and contested (see, e.g., Chaffin et al. 2014).

This broader governance perspective positions law not as a simple "barrier" to learning for social-ecological resilience, to be placed somehow in opposition to science, but as a participant in the coproduction of learning (Jasanoff 1997). Accordingly, there is increasing interest in the literature on social-ecological resilience in the ways that legal principles and processes may enhance adaptive decision making in environmental governance and may in fact ease the "social barriers" to implementing adaptive management (Cosens and Williams 2012, Cosens 2013, Garmestani and Benson 2013, Garmestani and Allen 2014). For instance, in the recent special feature of Ecology and Society, "Law and Social-Ecological Resilience," Cosens (2013) explores how participatory legal procedures and coordination across scales of governance may promote accountable and legitimate forms of ecological experimentation. Meanwhile, Garmestani and Benson (2013) propose that the adoption of reflexive law principles that allow for substantive environmental goals to emerge through "democratic self-regulatory mechanisms" and encourage learning in legal systems may be an effective model to govern for socialecological resilience.

Collectively, the contributions to the special feature of Ecology and Society problematize the intuitive view of the relations between law and resilience outlined previously. Indeed, although law may seek to provide certainty in some circumstances, the viability of legal systems rests on their ability to provide for deliberation between evolving social values, norms, and ideas of justice in relation to developments in scientific and other forms of knowledge (Ebbesson 2010, Ebbesson and Folke 2014, Garmestani and Allen 2014). In this sense, law has a potentially powerful role to play in stimulating learning by mediating between various equally valid conceptions of social-ecological systems inevitably informed equally by notions of what is "right" and what is "true." Ebbesson and Hey (2013) identify three areas of priority for the study of law and social-ecological resilience: adjudication in environmental lawmaking, the role of nonenvironment-focused legal regimes on environmental issues, and the interaction of different jurisdictional legal scales.

We seek to contribute to these priorities by presenting an analysis of environmental cases in the European Court of Human Rights (ECtHR). A rights framing of environmental change focuses attention on the multiscalar interplay between individual rights, public interests, and state responsibilities, and on how environmental risks and opportunities are known and distributed between actors. This deliberation, practiced through adjudication in the courtroom, differs substantially from the traditional realm of environmental law and the focus of much of the law and resilience literature to date: statutory and administrative law. Does international legal adjudication of environmental cases within a rights framework help or hinder adaptive governance of socialecological systems? First, we identify 3 proxies for adaptive governance: use of multiple forms of knowledge, support for adaptive policy making and management, and support for polycentricity. We then examine how European human rights law frames adjudication of environmental cases, before analyzing the transcripts of 12 environmental cases heard by the ECtHR between 1990 and 2009. In the Discussion, we examine the extent to which the adjudicative practice of the ECtHR supports our proxies for adaptive governance.

\section{PROXIES FOR ADAPTIVE GOVERNANCE}

\section{Use of multiple forms of knowledge}

Dietz et al. (2003), Brunner et al. (2005), and Folke et al. (2005) identify the use of multiple forms of knowledge as a crucial facet of adaptive governance, building on the insight from Berkes and Folke (2002) that local and indigenous ecosystem knowledge can contribute to scientific knowledge in managing ecosystems, and from Berkes et al. (2003) that knowledge from the social sciences, humanities, and natural sciences is essential for understanding social-ecological systems. Nevertheless, this pluralism has been difficult to establish in practice. As described previously, modernist approaches to environmental governance have prioritized scientific information above other ways of knowing the environment, including experiential, local, and indigenous knowledge, as well as forms of knowing based explicitly on social, cultural, or humanistic values. To what extent does the ECtHR facilitate the interaction between multiple ways of knowing in deliberation of environmental cases?

\section{Support for adaptive policy making and management}

Dietz et al. (2003), Folke et al. (2005), and Gunderson and Light (2006) identify adaptive governance as a crucial enabling condition for adaptive management. Adaptive management is a process "wherein policies become hypotheses, and management actions become the experiments to test those hypotheses" (Folke et al. 2005:447). However, Arnold and Gunderson (2013) suggest that the U.S. legal system seeks top-down "optimal instrument" solutions to problems, restricting adaptive management. How does the ECtHR, operating in a European context, affect possibilities for adaptive policy making and management in its member states?

\section{Support for polycentricity}

Polycentricity has been identified as necessary for, and as an expression of, adaptive governance (Chaffin et al. 2014). Adaptive governance, for Olsson et al. (2006), "relies on polycentric institutional arrangements that are nested, quasi-autonomous decision-making units operating at multiple scales." Related to the concept of modularity in network studies and to legal pluralism in legal studies, polycentricity is defined by Aligica and Tarko (2012:237) as a social system "of many decision centres having limited and autonomous prerogatives and operating under an overarching set of rules." To what extent does the ECtHR restrict or enhance polycentricity regarding environmental matters? 


\section{CASE HISTORY AND DESCRIPTION: HUMAN RIGHTS, THE ENVIRONMENT, AND THE EUROPEAN COURT OF HUMAN RIGHTS}

International law emerges through customary law, general principles, and treaty law, and it is primarily applicable to nationstates (Boyle and Chinkin 2007). These various legal principles, treaties, and norms are aligned along an evolving and often contested spectrum from "soft" to "hard" law, in terms of how binding they are on states. Increasingly, international law has been made and applied by judicial bodies in specialist regimes; for instance, the dispute settlement mechanisms of the World Trade Organization (WTO 1994), the United Nations Convention on the Law of the Sea (United Nations 1982), and the European convention on human rights (ECHR; COE 1950, Buergenthal 2001, Boyle and Chinkin 2007, Shigeta 2010). The ECtHR serves as the adjudicative body for the ECHR. State signatories are compelled to appear before the ECtHR for alleged violations of the ECHR in their domestic actions and accept that ECtHR decisions will be binding on the national government. Signed in 1950 in the aftermath of World War II, the ECHR serves to protect a range of "inalienable" human rights and fundamental freedoms in its 47 signatory states. Conceived as a response to the statutorily acceptable actions of genocide, this emergent human rights regime was an attempt to reassert an intrinsic connection between law and morality and to provide some form of legal recognition to the individual within international law (Sohn 1982, Steiner and Alston 2000, Gearty 2004). Human rights work to frame both legal and philosophical debate in terms of a balance between instrumental and intrinsic value, with a focus on the interplay between individual, community, and state (Twining 2009).

The treatment of environmental issues within a human rights framework has been somewhat controversial (e.g., Pathak 1992, Stallworthy 2005). The confidence displayed by legal modernism in scientific knowledge as an objective way of knowing the environment has ensured that environmental issues have generally been considered the sole preserve of statutory and administrative law (Coyle and Morrow 2004). The perception of adjudication as concerned merely with establishing winners and losers has meant that it has been often considered unsuitable for environmental cases that one might think can be known "objectively" (Jasanoff 1997). However, since the 1970s there have been persistent attempts to extend human rights frameworks to cover environmental issues, spurred by the recognition that a healthy environment is integral to the fulfillment of human dignity and autonomy and situated within the broader trend toward public participation and access to justice in environmental law (Boyle 2003, Sands 2003, Merrills 2007). These attempts have been hobbled by competing interpretations of what the normative application of human dignity means in general, and in the context of the environment in particular (Schachter 1983, Young 2008). On the one hand, individual human dignity is considered a transcendent quality or "trump card" derived from simply "being human" (Dworkin 1977). On the other, human dignity is an immanent value or "optimization requirement," constructed within particular cultural contexts, to be shuffled with other types of value (Alexy 2002). This division has produced two distinct types of environmental right: substantive, e.g., "the right to a clean environment," and procedural, e.g., access to information, public participation in decision making, and justice in environmental matters (Shelton 2006).
The ECHR itself does not contain an explicit environmental right of either kind but has rather embarked on a progressive interpretation of existing rights as containing an environmental component that has both substantive and procedural elements (Desgagné 1995, Fitzmaurice and Marshall 2007). Consequently, in light of the effects of environmental degradation on enjoyment of protected ECHR rights to, for instance, enjoyment of private life and home (COE 1950: Article 8), and freedom from torture and degrading treatment (COE 1950: Article 3), the ECtHR has heard an increasing number of "environmental" cases.

The ECtHR uses a variety of legal tools to normatively apply the concept of human dignity in environmental cases. The doctrine of "autonomous concepts" is applied in areas where the ECtHR feels it is able to derive an autonomous and stable truth behind language contained in the ECHR. The "balance of interests" allows the ECtHR to weigh the duty of member states to respect individual rights against their concurrent responsibility to legislate on behalf of society as a whole. The "margin of appreciation" delimits the freedom that a member state enjoys to regulate matters according to its own particular needs and context; states are normally allocated a wide margin in environmental cases.

Deliberation of environmental cases in the ECtHR generally takes place in three stages: assessment of harm suffered by the applicant, assessment of the sufficiency of a state's legal-political apparatus to safeguard individual human dignity in the context of the state's responsibility to legislate for the broader public good, and the final substantive judgment on the appropriate balance of interests between individual, community, and state. Admissible cases are first heard by a chamber of the ECtHR. Chamber judgments may be referred to the Grand Chamber in exceptional circumstances, or cases may be relinquished by a chamber to the Grand Chamber if they raise a serious question affecting the interpretation of the ECHR or if there is a risk of inconsistency with a previous judgment of the court. We use "the ECtHR" and "the court" to refer to the court in general; differences between chamber and Grand Chamber judgments are specified where appropriate.

We trace the reasoning of the ECtHR through these 3 stages of deliberation with reference to 12 environmental cases heard from 1990 to 2009 (expanding on a provisional analysis presented in West 2011). The cases discussed refer to an alleged violation of Article 8 unless otherwise stated, which reads as follows:

\section{Everyone has the right to respect for his private and family life, his home and his correspondence.}

2. There shall be no interference by a public authority
with the exercise of this right except such as is in
accordance with the law and is necessary in a democratic
society in the interests of national security, public safety
or the economic wellbeing of the country, for the
prevention of disorder or crime, for the protection of
health or morals, or for the protection of the rights and
freedoms of others. (COE 1950: Article 8)

We then analyze the extent to which our three proxies for adaptive governance, i.e., the use of multiple forms of knowledge, support for adaptive policy making and management, and support for polycentricity, are addressed through the practice of the court. 


\section{RESULTS: ENVIRONMENTAL ADJUDICATION IN THE EUROPEAN COURT OF HUMAN RIGHTS}

\section{Establishing harm and causation}

In cases of alleged environmental harm, the ECtHR initially determines whether the degree of harm suffered is enough to constitute a violation of the human right in question, and then whether a causal relationship exists between the harm suffered by the applicant and the alleged harmful activity undertaken or permitted by the state. The court has recognized that environmental harm will be to some degree relative rather than absolute, and therefore, that establishing harm requires mediation between the subjectivity of individual environmental experience, including social and environmental context, and medical assessment. In practice, scientific evidence of direct causality is rarely established, in part because of the inherent uncertainties of science and in part because of the subjectivities of environmental harm, and the court has consequently been willing to infer causality from a sufficiently high, but loosely defined, level of risk.

In some circumstances, applicants have clearly suffered considerable harm, and causality is relatively easy to infer. For instance, the case Oneryildiz v. Turkey (2004), considered largely under Article 2 of the ECHR, concerned the collapse of a rubbish dump, resulting in 39 deaths and 10 flattened houses (Oneryildiz 2004: para. 18). Scientific investigation conducted by, amongst others, the Ministry of Environment and Bogazici University concluded with high certainty that a relationship of cause and effect existed between increasing levels of methane resulting from pressure created by mounting waste and the consequent explosion and landslide (Oneryildiz 2004: paras. 23-28).

However, it becomes more difficult to establish harm and causality in relation to the more subtle and diffuse effects of air and noise pollution. Gregoria López Ostra, initiating the case López Ostra v. Spain (1994), claimed that the smell, noise, and contamination caused by a neighboring waste treatment plant violated her rights under Article 8 and Article 3, i.e., the right to physical integrity, under the ECHR. Despite the existence of several medical certificates indicating symptoms such as nausea, vomiting, allergic reactions, anorexia, and acute bronchopulmonary infections among members of Mrs. López Ostra's family, it was disputed by the Spanish defense whether the contamination constituted a "serious risk" to Mrs. López Ostra's health. However, the ECtHR considered medical proof of harm unnecessary, stating that environmental pollution "can affect individuals' well-being and prevent them from enjoying their homes in such a way as to affect their private and family life adversely, without, however, seriously endangering their health" (López Ostra 1994: para. 51). These criteria introduce a "subjective element" (Hatton and Others v. the United Kingdom 2003: para. 118) into the assessment of harm, which works to "fill in the gaps" left by scientific information. This aspect of material experience is assessed by the ability of the applicant to enjoy a life of dignity, in reference to the particular right in question, and conditioned by the social and environmental context in which that right is exercised. In López Ostra, the court accepted that the experiential testimony, medical reports, and technical expert opinion submitted by Mrs. López Ostra indicated enough harm to support a claim under Article 8 (López Ostra 1994: paras. 44-51).
In terms of causal relationships, a body of scientific research conducted variously by the University of Murcia, the National Toxicology Institute, and the Environment and Nature Agency suggested that there could be a causal link between the polluting plant and the ill health of Mrs. López Ostra's family, but it was incapable of establishing a direct cause-and-effect relationship (López Ostra 1994: paras. 18-19, 49). Likewise, in Guerra and Others v. Italy (1998: para. 65), the applicants contended that a chemical factory had caused substantial harm to the local population but failed to demonstrate that they had sustained any scientifically verifiable damage from the factory. However, in both cases, the court established causality in practice by noting that the activity in question increased risk to the applicants and that the defendant state failed to act sufficiently to ameliorate this risk.

Russian citizen Nadezhda Mikhai Fadeyeva initiated the case Fadeyeva v. Russia (2005), arguing that the Russian government's failure to resettle her from an area of high industrial pollution caused her health to deteriorate and constituted a violation of her Article 8 rights. In Fadeyeva, elaborating on the standard set in López Ostra v. Spain (1994) and Kyrtatos v. Greece (2005), the court declared that given the lack of an explicit right to nature preservation within the ECHR, environmental pollution must attain a "certain minimum level" and "show interference with the applicant's private sphere" if it is to fall within the scope of Article 8 (Fadeyeva 2005: para. 70).

The assessment of that minimum [level of pollution] is
relative and depends on all the circumstances of a case,
such as the intensity and duration of the nuisance, and
its physical or mental effects. The general context of the
environment should also be taken into account. There
would be no arguable claim under Article 8 if the
detriment complained of was negligible in comparison to
the environmental hazards inherent to life in everymodern
city. (Fadeyeva 2005: para. 69)

Establishment of harm therefore relies on interpolation of the multiple aspects of individual experience with environmental and social context. In the case of Fadeyeva, the applicant suffered from a range of illnesses affecting the nervous system (Fadeyeva 2005: paras. 44-47). Although the Russian government did not dispute the existence of these illnesses or that pollution levels in the area exceeded statutory environmental thresholds, it claimed that Nadezhda Fadeyeva's illnesses were "occupational" and not uncommon among persons of her age and occupation, i.e., covering industrial material with thermoinsulating materials. The government denied that the illnesses were specifically attributable to the polluting plant in question (Fadeyeva 2005: paras. 74-78). The question of causality therefore became critical.

In such complex environments, determining causality with any certainty may prove extremely difficult. Indeed, in Ledyaeva Dobrokhotova, Zolotareva and Romashina v. Russia (2006), a case concerning the same polluting industrial plant as Fadeyeva, the court declared that "it is often impossible to quantify the effects of industrial pollution in every case, and distinguish them from other relevant factors such as age, profession, etc." (Ledyaeva 2006: para. 90). Therefore, in the Fadeyeva and Ledyaeva cases, rather than proving causality, the court used the government's own statistics, the experiential testimony of the applicant, and expert submissions to indicate sufficient risk to the applicant: "Even assuming the pollution did not cause any quantifiable harm 
to her health, it inevitably made the applicant more vulnerable to various illnesses. Moreover, there can be no doubt that it adversely affected her quality of life at home" (Fadeyeva 2005: para. 88). The court has been increasingly willing to infer causality from a loosely defined concept of risk, not necessarily requiring verifiable measurement. Therefore, causality is established in practice if the link between the activity and the harm suffered by the applicant is "reasonable," and if the authorities fail to take "positive action" to ensure that human rights are respected (Hatton 2003: para. 118).

\section{Sufficiency of the domestic regulatory regime}

After establishing a sufficient degree of harm, the court will examine whether the regulatory structures in the defendant state provide for prudent assessment of environmental risk and policy implementation on the basis of relevant information (Hatton 2003: para. 104). This analysis of procedural safeguards is not limited to commission of technical information gathering but will also be conditioned by substantive obligations and rights guaranteed by either the domestic constitution, e.g., a substantive environmental right, or by international law, e.g., environmental law principles, such as precaution, transboundary harm, and liability, and human rights norms, such as human dignity and the rule of law. The jurisdictional powers of the ECtHR have proved adept, for instance, at enforcing social, cultural, and economic rights guaranteed in domestic constitutions but where there has been poor or completely absent implementation (Pedersen 2008, 2010).

In Taskin and Others v. Turkey (2004), the court considered the compliance of Turkish authorities and the effectiveness of the legislative framework in fulfilling the constitutional right to live in a "healthy, balanced environment," in light of permission granted by the domestic government to a gold-mining operation in a rural agricultural area (Taskin 2004: para. 90). Although domestic statutory law ensured that an environmental impact assessment (EIA) was performed, which appraised "the physical, ecological, aesthetic, social and cultural effects" of the mine and produced a highly critical report, the Turkish Ministry of Environment granted the mine permission to operate (Taskin 2004: para. 26). The Turkish Supreme Administrative Court, on account of a judicial review requested by local residents, held that the EIA demonstrated that the mine posed significant risk to local populations and ecosystems and ruled the mine effectively illegal. However, the executive ignored this supreme court decision and persevered with the mine. Despite the absence of any scientifically proven ill effects caused by the mine, the court found a violation of human dignity, stating:

\begin{abstract}
Article 8 applies to severe environmental pollution which may affect individuals' well-being and prevent them from enjoying their homes in such a way as to effect their private and family life adversely, without, however, seriously endangering their health ... The same is true where the dangerous effects of an activity to which the individuals concerned are likely to be exposed as part of an environmental impact procedure in such a way as to establish a sufficiently close link with private and family life for the purposes of Article 8 of the Convention. (Taskin 2004: para. 113)
\end{abstract}

In this case, the failure of the Turkish executive to follow the established domestic regulatory apparatus was crucial in finding against the defendant state. However, the practice of the ECtHR emphasizes that following procedure is important primarily in the context of substantive goals. Fulfillment of Article 8 obligations by the state with respect to environmental degradation or nuisance are therefore held by the court to include both a procedural and a substantive aspect, following the standard set in Guerra (Taskin 2004: para. 115).

The court has increasingly derived substantive content from international environmental law norms to guide appraisal of domestic regulation. In Taskin, the court referred to "soft law" and treaty texts such as the Rio Declaration on Environment and Development (General Assembly of the United Nations 1992); Recommendation 1614 (Parliamentary Assembly of the Council of Europe 2003); and the Aarhus Convention on Access to Information, Public Participation in Decision-Making and Access to Justice in Environmental Matters (UNECE 1998), to which Turkey was not a party, to identify Turkey's obligations under the constitutionally guaranteed right to a "healthy, balanced environment" (Taskin 2004: para. 90). In Oneryildiz, the court referred to the Lugano and Strasbourg conventions (COE 1993, 1998), which are yet to enter into force, and various Council of Europe recommendations in assessing the responsibility and liability of the local authorities in terms of waste management (Oneryildiz 2004: paras. 59-62). In Tatar v. Romania (2009), concerning the alleged ill effects of a gold mine on the health of the applicants, the court referred to the Stockholm and Rio declarations (General Assembly of the United Nations 1972, 1992), an excerpt from the International Court of Justice's judgment in Gabčikovo-Nagymaros (1998), and, amongst other sources, the precautionary and transboundary harm principles in outlining Romania's obligation to fulfill its people's constitutional right to live in a "healthy and balanced environment" (Shelton 2010:107).

Where the defendant state offers no substantive constitutional right to citizens, the court provides a wider margin of appreciation to the defendant state to legislate for environmental quality, in line with the court's general approach to environmental cases (Hatton 2003: para. 100). However, domestic regulation remains to be scrutinized by the court. For example, the scope of the margin of appreciation will be narrower for incidences that affect particularly "intimate" rights; therefore, the environmental component of Article 8 provides a weak substantive guarantee in these circumstances (Hatton 2003: para. 103). Procedurally, domestic impropriety will be decided on the basis of the type of policy or decision involved, public participation in the decisionmaking procedure, and the availability of procedural safeguards (Hatton 2003: para. 104).

The case Hatton and Others v. the United Kingdom (2003) was brought by eight applicants who complained that the UK government's policy on night flights at Heathrow Airport violated their ECHR rights under Article 8 and Article 13, i.e., the right to an effective domestic remedy. The initial ECtHR chamber that heard the case criticized the UK government's regulatory regime, identifying a failure to commission independent research to critically assess the contribution of night flights to the national economy, i.e., the economic value of Heathrow Airport was the government's primary defense, and limited research regarding the effects of flights on sleep deprivation. The chamber stated that the poor quality and quantity of scientific information gathered 
rendered the government incapable of providing a solution that was "least onerous ... [as] regards human rights" (Hatton 2003: para. 105). On appeal, however, the Grand Chamber interpreted favorably the government's provisions for adaptive policy making, noting:

A government decision-making process concerning complex issues of environmental and economic policy as in the present case must necessarily involve appropriate investigations and studies ... However, this does not mean that decisions can only be taken if comprehensive and measurable data are available in relation to each and every aspect of the matter to be decided. In this respect it is relevant that the authorities have consistently monitored the situation ... The position concerning research into sleep disturbance and night flights is far from static, and it was the government's policy to announce restrictions on night flights for a maximum of five years at a time, each new scheme taking into account the research and other developments of the previous period. (Hatton 2003: para. 128)

The Grand Chamber also noted that the applicants had failed to register their concerns with a consultation paper distributed prior to implementation of the night-flight regime, further stating that although cases such as López Ostra and Guerra involved procedural violations, "this element of domestic irregularity is wholly absent in the present case" (Hatton 2003: para. 120). Although the Grand Chamber overturned the chamber's decision, the substantive assessment of the regulatory regime in the Grand Chamber does suggest that a kernel of environmental quality remains to be protected by the ECtHR, regardless of the existence of a domestic constitutional right.

In recognizing that decisions must be taken in light of incomplete environmental data, the Grand Chamber provides room for government decision making to take into account social imperatives inspired by a collective vision of the good, conditioned by human dignity, which in turn allows for substantive criticism by the court of such an aspect of decision making. Moreover, a violation of Article 13 of the ECHR was found, which provides a right to "an effective remedy before a national authority notwithstanding that the violation has been committed by persons acting in an official capacity" (COE 1950: Article 13). The applicants, because of the statutory exclusion of liability in the Civil Aviation Act 1982, would only have been able to mount action in UK courts respective of noise disturbance in relation to "classic English public-law concepts, such as irrationality, unlawfulness and patent unreasonableness" and not based on the intrinsic nature of aircraft noise as violatory of ECHR protected rights (Hatton 2003: para. 141). This adjudication of the moral implications of statutory law was deemed essential to the protection of human rights under the ECHR.

\section{The margin of appreciation}

The conventional approach of the ECtHR is to insist that states enjoy a wide margin of appreciation in regulating environmental issues because of the characterization of environment as a "difficult social and technical sphere" (O’Donnell 1982, Powell \& Raynor v. United Kingdom 1990: para. 44, Taskin 2004: para. 116, Fadeyeva 2005: para. 104). It is affirmed that although "it remains open to the Court to conclude that there has been a manifest error of appreciation by the national authorities in striking a fair balance between the competing interests of different private actors in this sphere," its role will remain subsidiary (Fadeyeva 2005: para. 105). This reluctance to intrude is derived partly from the ECtHR's status as an international court relying on political support from member states for its continued existence, and partly because of recognition that desirable environmental conditions will vary between social and ecological contexts. States therefore enjoy a degree of choice in how to meet their obligations to protect rights contained in the ECHR (Hatton 2003: paras. 122-129, Greenpeace E.V. and Others v. Germany 2009). The court further clarifies that in coming to a conclusion it will assess both substantive and procedural aspects of a case (Fadeyeva 2005: para. 105). In this assessment, the court examines the suffering of the individual in the context of the legislative and judicial frameworks in place to regulate such harm with the goal of preserving human dignity.

In Fadeyeva, after establishing that there had been interference with the applicant's Article 8 rights, i.e., no causal link was found between pollution and individual harm to the applicant, but scientific evidence suggested an increased general risk to the community (Fadeyeva 2005: paras. 79, 88), the court heard from the defendant state that this interference was necessary on account of the economic interest to the wider community, and justifiable in the presence of an effective statutory regime for containing and reducing pollution and resettling the affected population (Fadeyeva 2005: paras. 101, 111, 122, 125). In a substantive assessment of the regime, the court noted that although there was a quantifiable reduction of pollution, the lack of documentation provided by the state meant that it was impossible to say whether due weight had been provided to the individual in the "due diligence" test. Although it was reasonable to assume that in existing Russian statutory law it was "correct" to place the applicant on a general waiting list for resettlement because there was no special treatment available to residents of heavily polluted areas, the court declared that given the exceptional situation around the plant, "special treatment" for affected citizens was in fact necessary and the state had acted outside of its margin of appreciation (Fadeyeva 2005: paras. 122, 133). This assertion was not based primarily on noncompliance with a scientifically defined harm threshold but rather on assessment of the cogency of a legal narrative of relation between society and nature. A textual analysis of domestic Russian law conducted by the court suggested that there was a statutory recognition that contaminants had reached "unsafe" levels, and a qualitative assessment of the social value of the environment in Russia and elsewhere suggested that "in recent decades environmental pollution has become a matter of growing public concern" (Fadeyeva 2005: para. 103).

In Hatton, the government declared that the instrumental value of night flights into Heathrow Airport was beneficial to the wider community, whereas the applicants cited the intrinsic value of being able to sleep and enjoy the privacy of their home. In applying the margin of appreciation, the chamber identified the government's "sleep study" as an inadequate means by which to construct policy respectful of individual rights as well as collective interests, noting, "Mere reference to the economic well-being of the country was not sufficient to outweigh the rights of others" (Hatton 2003: paras. 86, 105). The Grand Chamber, however, accepted that the authorities were "entitled ... to rely on statistical 
data based on average perception of noise disturbance," stating that decisions do not have to be put on hold until "comprehensive and measurable data are available in relation to each and every aspect of the matter to be decided" (Hatton 2003: paras. 125, 128). Despite a failure to quantify the value of night flights, again because of the difficulty of measurement and gathering of information, the court considered it "reasonable to assume that those flights contribute at least to a certain extent to the general economy," deciding that the UK government had acted within its margin of appreciation in its regulation of Heathrow (Hatton 2003: para. 126).

\section{DISCUSSION}

This brief analysis of environmental cases within the ECtHR provides an overview of how adjudication proceeds. What support do we see for our adaptive governance proxies?

\section{Use of multiple forms of knowledge}

Although the ECtHR does have the authority to conduct its own fact-finding investigations, in practice and in all of the cases we refer to it usually relies on secondary sources. This produces a range of problems, in particular the potential reliance on unreliable information and the lack of guidelines for weighting secondary sources (Sadeghi 2009). Nevertheless, the court does use a broad range of information to establish the "minimum threshold" of harm in environmental cases, including scientific reports by universities and government agencies, expert opinions, and experiential testimony. Although there is no example as yet of the court explicitly admitting "local" or "traditional" ecological knowledge, the admittance of experiential testimony would seem to suggest that the court would have little difficulty in doing so if relevant. Indeed, the court is to a substantial degree compelled to use multiple forms of knowledge because the subjectivities and complexities of tracing environmental harm mean that the science is almost never absolutely clear.

Rather, difficulties arise when weighting the value of the evidence received. As noted in Fadeyeva, the court has recognized that the "general context of the environment" should be taken into account when establishing harm. In environmental management terms, this may be interpreted as the "desired state" of the environment in question. It is impossible to determine this "desired state" scientifically because it is an inherently valuebased decision and may therefore be contested among parties (Chaffin et al. 2014). Likewise, although a certain degree of harm may be assessed scientifically, it is impossible to scientifically determine whether this harm constitutes a violation of human dignity. For Beck (2008:216), writing in general terms, this essential contestability coupled with value pluralism "means that human rights adjudication inevitably and habitually involves contestable value judgments."

In response to these complexities, the court appears to be progressively relying on finding a violation of domestic law by the defendant state to confirm that the applicant has suffered sufficiently to bring a case under Article 8, rather than exhaustively reviewing evidence of individual harm, explicitly referring to the precautionary principle for the first time in Tatar $v$. Romania. This is congruent with the court's willingness to determine environmental harm through a loosely defined risk threshold that takes into account existing legislative frameworks regulating environment, the general environmental context of the applicant, and the nature of the alleged harm. Therefore, although scientific information is often used to suggest a certain degree of harm, unanimous scientific opinion is by no means necessary, or even sought; rather, the ECtHR often relies on experiential evidence supplied by the applicant.

Correspondingly, where the substance of scientific information is weighted particularly heavily in a decision this is performed rather uncritically and appears to be employed to back up a decision made on the basis of other evidence or principle. For instance, in Fagerskiold v. Sweden (2008: paras. 16-17), a case brought by a Swedish citizen who complained that the noise from a nearby wind farm violated his Article 8 rights, the significant weight placed by the ECtHR on noise guidelines produced by the World Health Organization (WHO) in favor of the defendant state appears to be exaggerated and emphasized because of the absence of any competing evidence produced by the applicants, rather than the scientific accuracy of the WHO guidelines themselves. The reason for this weighting toward principle appears to reside in the court's orientation toward establishing the correct structures for environmental regulation at the state level. Therefore, it is unlikely to establish harm if adaptive policy making takes place in tandem with public participation and consultation at the local level.

Overall, despite this unevenness of application, the court is certainly willing to admit multiple types of evidence into deliberation. Furthermore, the interpretation of scientific information through the prism of human rights works to reveal the complex interactions between values and empirical experience inherent to any "knowing" of environmental change. Kennedy (1997) provides a useful way of thinking about how rights concepts aid deliberation between value judgments, characterized by preference and subjectivity of views, and factual judgments, which represent decisions based on empiricism and scientific study. For Kennedy, the nature of rights as both "universal," in the sense that they represent values shared broadly, and "factoid," because there must be an ability to derive specific criteria for achieving such values, allows them to perform the role of mediator effectively. In this sense, the language of rights rejects a strict delimitation between truth and justice, providing a useful means of reconciling "technical" and "principled" forms of knowing in ways that may aid deliberative forms of adaptive governance.

\section{Support for adaptive policy making and management}

The court will assess the sufficiency of a defendant state's environmental regulation to enable effective and equitable decision making at the national level. In the context of the "complex issues of environmental and economic policy," this does not mean obtaining complete and certain scientific information, but rather implementing policy on the basis of an ongoing program of monitoring, feedback, and information sharing. The ECtHR is therefore actively supportive of adaptive policy making and management.

However, it is important to note that such policy making must also give meaning to substantive commitments contained in the ECHR and within the state's domestic constitution, e.g., any right to a clean or healthy environment. The content of these substantive provisions is, if necessary, elaborated by the case law of the ECtHR along with the broader tapestry of international law norms. In environmental cases, this may include the Aarhus convention (UNECE 1998) and the Rio convention (General 
Assembly of the United Nations 1992), among others. This ensures that in any process of adaptive policy making or management that has the ability to affect ECHR protected rights, citizens enjoy the right to participate in decision making, have access to relevant information, and enjoy access to justice. Importantly, it also means that citizens should have the ability to challenge the substantive "ends" of policy making as they affect ECHR rights, not merely implementation of procedural provisions.

Therefore, in the context of the ECtHR, the tension between the "flexibility" required by adaptive management and the "certainty" required by law, identified by the resilience for law literature, does not carry significant weight. The flexibility of states to experiment is ensured in the context of procedural provisions that ensure democratic participation in both the "means" and the "ends" of any policy process. The ECtHR places adaptive management and policy making in the context of a public discussion about the relative distribution of rights and responsibilities. The practice of the court supports the findings of Cosens (2013) that any such tension between flexibility and legitimacy can be ameliorated through procedural elements, knowledge exchange, and coordination across scales of governance, as long as there are also substantive guarantees that give meaning to procedural rules.

Furthermore, the incremental development of human rights law relating to the environment through judicial lawmaking is in itself adaptive. The evolving jurisprudence of the court, evidenced by the progressive reading of Article 8 to include an environmental component and informed by the development of international standards of environmental law and good governance, indicates a lawmaking process that incorporates relative degrees of flexibility and certainty within its own practice. Theoretically speaking, the practice of the court therefore supports a version of adaptive governance that incorporates deliberation and reflexivity (Leach et al. 2010, Garmestani and Benson 2013).

\section{Support for polycentricity}

In a polycentric social system, there are many decision centers enjoying "limited and autonomous prerogatives and operating under an overarching set of rules" (Aligica and Tarko 2012:237). In this system, "no one has an ultimate monopoly over the legitimate use of force and the 'rulers' are constrained and limited under a "rule of law"' (Aligica and Tarko 2012:245). The rule of law is therefore crucial to polycentric systems.

International law in general can be seen as displaying characteristics of polycentrism, in that states submit willingly and in a self-organized fashion to laws that determine the "rules of the game" while retaining a large degree of lawmaking autonomy (Boyle and Chinkin 2007). In the ECtHR, the margin of appreciation is the primary mechanism whereby the court delimits the degree of autonomy provided to states and, subsequently, has attracted much controversy. For some, the liberal application of the doctrine "sells the judiciary short" by prioritizing a consensual approach to morality at the expense of an autonomous and universally attainable concept of what is "right" (Letsas 2004, Greer 2006); for others, the balancing of rights shows that deliberation of morality belongs in the political rather than the judicial sphere (Koskenniemi 1999). A third view, although supportive of the general concept of the margin of appreciation, decries the court's haphazard application of the doctrine (Hyam
2003). In particular, the Grand Chamber's attempt to classify, in Hatton, a universal "wide" margin of appreciation for environmental cases has been declared lazy, the view being put forward that rather than a binary tool either "wide" or "narrow," the doctrine rightly constitutes "a sliding scale [on which the appropriate margin is] dependent on context" (Hyam 2003:640).

We argue, building on Hilson (2013), that the margin of appreciation is the prism through which polycentrism is established, and therefore works to mediate between evolving and sometimes competing conceptions of universality and contingency, substantive and procedural law, and between the environmental rights, duties and responsibilities of individuals, communities, and states. Crucial for appreciating this function of the margin of appreciation is to understand the role of European human rights law in ensuring adherence to the rule of law in member states, which is central to any polycentric system. As Gearty (2004:19) points out, human rights instruments are largely "a reaffirmation of human dignity intended to inform rather than predetermine political debate"; their role is to help conceptualize legal and political debate in terms of "a devotion to human dignity which is on the one hand qualified by a realistic sensitivity to the democratic status quo and on the other fortified by a commitment to legality." It is in this context that the "inalienable" rights protected under the ECHR are conditioned by limitations justifiable by recourse to, for instance, economic well-being or the protection of health or morals, but that these intrusions are themselves conditioned by the requirements of accordance to the rule of law and the conventions of a democratic society (Gearty 2004).

The ECtHR therefore seeks to support the evolution of environmental policy making in member states in accordance with the rule of law, informed by evolving conceptions of the value of the environment and democratic conventions such as public participation and access to information. Finally, in fulfilling Ostrom's (1972) “three conditions" of spontaneity in polycentric systems, i.e., freedom of entry and exit, incentives for participants to enforce general rules of conduct, and provision for reformulation and revision of the basic rules, the ECtHR supports the autonomy of member states within an adaptive framework of guiding norms and principles. The ECtHR therefore enhances polycentricity at the European scale.

\section{CONCLUSION}

We have sought to contribute to the "law for resilience" literature by addressing some of the priorities identified by Ebbesson and Hey (2013): (1) adjudication in the courtroom, (2) "environmental" lawmaking outside the traditional sphere of statutory and administrative environmental law, and (3) the interaction of different legal instruments and jurisdictions across scales. We have done this by asking how adjudication of environmental cases in the ECtHR may help or hinder adaptive governance, using three proxies. We have found that the practice of the court facilitates the interaction of different ways of knowing the environment, supports adaptive environmental policy making by member states, and enhances polycentricity at the European scale. These findings indicate that the contradictions between law and resilience identified at the scale of local adaptive management, including flexibility versus certainty and truth versus justice, may not be pertinent for legal regimes operating at broader scales and with different tool sets. 
The court, rather than seeking to impose transcendent and certain justice on member states, seeks to help states develop effective domestic governance arrangements that allow for adaptive deliberation between evolving conceptions of equity and justice, as well as varying dimensions of flexibility and certainty, in relation to environmental change, regulation, and continually shifting knowledge. This more facilitative role, albeit implemented with binding force, is arguably a product of the court's international status; correspondingly, the adaptive nature of judicial decision making with a living document such as the ECHR stands in contrast to the often static provisions of statutory and administrative law.

Indeed, rather than hindering learning for ecological resilience, we propose that the practice of the ECtHR enhances learning for social-ecological resilience in two primary ways. First, the ECtHR supports the development of adaptive policy making and management in member states in the context of access to information, public participation, and access to justice. In this sense, the adjudicative practice of the court influences the legislation of member states, acting as a site of learning driving change in environmental governance. Second, the argumentative grammar of rights adjudication submits knowledge and experience of environmental change to deliberation in terms of individual rights, public interests, and state responsibilities. This illuminates the contested and negotiated character of resilience in social-ecological contexts, in ways that may inform future research on the connections between deliberation, reflexivity, and adaptation in the governance of social-ecological systems.

\section{Responses to this article can be read online at:} http://www.ecologyandsociety.org/issues/responses. $\mathrm{php} / 7190$

\section{LITERATURE CITED}

Alexy, R. 2002. A theory of constitutional rights. Oxford University Press, Oxford, UK.

Aligica, P., and V. Tarko. 2012. Polycentricity: from Polanyi to Ostrom, and beyond. Governance: An International Journal of Policy, Administration, and Institutions 25(2):237-262. http://dx. doi.org/10.1111/j.1468-0491.2011.01550.x

Arnold, C. A., and L. Gunderson. 2013. Adaptive law and resilience. Environmental Law Reporter 43:10426-10443.

Beck, G. 2008. Human rights adjudication under the ECHR: between value pluralism and essential contestability. European Human Rights Law Review 13(2):214-244.

Berkes, F., J. Colding, and C. Folke. 2003. Navigating socialecological systems: building resilience for complexity and change. Cambridge University Press, Cambridge, UK. http://dx.doi. org/10.1017/CBO9780511541957

Berkes, F., and C. Folke. 2002. Back to the future: ecosystem dynamics and local knowledge. Pages 121-146 in L. H. Gunderson and C. S. Holling, editors. Panarchy: understanding transformations in human and natural systems. Island, Washington, D.C., USA.
Boyle, A. 2003. The role of international human rights law in the protection of the environment. Pages 43-70 in A. Boyle and M. Anderson, editors. Human rights approaches to environmental protection. Oxford University Press, Oxford, UK.

Boyle, A., and C. M. Chinkin. 2007. The making of international law. Oxford University Press, Oxford, UK.

Brunner, R. D., T. A. Steelman, L. Coe-Juell, C. M. Cromley, C. M. Edwards, and D. W. Tucker. 2005. Adaptive governance: integrating science, policy, and decision making. Columbia University Press, New York, New York, USA.

Buergenthal, T. 2001. Proliferation of international courts and tribunals: is it good or bad? Leiden Journal of International Law 14:267-275. http://dx.doi.org/10.1017/S0922156501000139

Carpenter, S., B. Walker, J. M. Anderies, and N. Abel. 2001. From metaphor to measurement: resilience of what to what? Ecosystems 4:765-781. http://dx.doi.org/10.1007/s10021-001-0045-9

Chaffin, B. C., H. Gosnell, and B. A. Cosens. 2014. A decade of adaptive governance scholarship: synthesis and future directions. Ecology and Society 19(3): 56. http://dx.doi.org/10.5751/ ES-06824-190356

Cosens, B. 2008. Resolving conflict in non-ideal, complex systems: solutions for the law-science breakdown in environmental and natural resource law. Natural Resources Journal 48:257-301.

Cosens, B. A. 2013. Legitimacy, adaptation, and resilience in ecosystem management. Ecology and Society 18(1): 3. http://dx. doi.org/10.5751/ES-05093-180103

Cosens, B. A., and M. K. Williams. 2012. Resilience and water governance: adaptive governance in the Columbia River basin. Ecology and Society 17(4): 3. http://dx.doi.org/10.5751/ ES-04986-170403

Council of Europe (COE). 1950. Convention for the protection of human rights and fundamental freedoms (Rome, 4 November 1950). 213 United Nations Treaty Series 221 (European Treaty Series No. 5). COE, Strasbourg, France.

Council of Europe (COE). 1993. Convention on civil liability for damage resulting from activities dangerous to the environment (Lugano, 21 June 1993). European Treaty Series No. 150. COE, Strasbourg, France.

Council of Europe (COE). 1998. Convention on the protection of the environment through criminal law (Strasbourg, 4 November 1998). European Treaty Series No. 172. COE, Strasbourg, France.

Coyle, S., and K. Morrow. 2004. The philosophical foundations of environmental law: property, rights, and nature. Hart, Oxford, UK.

Cundill, G., A. M. Leitch, L. Schultz, D. Armitage, and G. Peterson. 2015. Principle 5: encourage learning. In R. Biggs, M. Schlüter, and M. L. Schoon, editors. Principles for building resilience: sustaining ecosystem services in social-ecological systems. Cambridge University Press, Cambridge, UK, in press.

Desgagné, R. 1995. Integrating environmental values into the European convention on human rights. American Journal of International Law 89:263-294. http://dx.doi.org/10.2307/2204204 
Dietz, T., E. Ostrom, and P. C. Stern. 2003. The struggle to govern the commons. Science 302(5652):1907-1912. http://dx.doi. org/10.1126/science.1091015

Dryzek, J. S. 2000. Deliberative democracy and beyond: liberals, critics, contestations. Oxford University Press, Oxford, UK.

Dworkin, R. 1977. Taking rights seriously. Duckworth, London, UK.

Ebbesson, J. 2010. The rule of law in governance of complex socioecological changes. Global Environmental Change 20:414-422. http://dx.doi.org/10.1016/i.gloenvcha.2009.10.009

Ebbesson, J., and C. Folke. 2014. Matching scales of law with social-ecological contexts to promote resilience. Pages 265-292 in A. S. Garmestani and C. R. Allen, editors. Social-ecological resilience and law. Columbia University Press, New York, New York, USA.

Ebbesson, J., and E. Hey. 2013. Introduction: where in law is social-ecological resilience? Ecology and Society 18(3): 25. http:// dx.doi.org/10.5751/ES-05750-180325

Fadeyeva v. Russia, (2005) 45 EHRR 10.

Fagerskioldv. Sweden, (App. no. 37664/04) ECtHR admissibility hearing, 26 February 2008.

Fitzmaurice, M., and J. Marshall. 2007. The human right to a clean environment - phantom or reality? The European Court of Human Rights and English courts perspective on balancing rights in environmental cases. Nordic Journal of International Law 76:103-151. http://dx.doi.org/10.1163/090273507X225729

Folke, C. 2006. Resilience: the emergence of a perspective for social-ecological systems analyses. Global Environmental Change 16:253-267. http://dx.doi.org/10.1016/j.gloenvcha.2006.04.002

Folke, C., T. Hahn, P. Olsson, and J. Norberg. 2005. Adaptive governance of social-ecological systems. Annual Review of Environment and Resources 30:441-473. http://dx.doi.org/10.1146/ annurev.energy.30.050504.144511

Gabčikovo-Nagymaros Project (Hungary/Slovakia), Judgment, Merits, (1998) 37 ILM 162.

Garmestani, A. S., and C. R. Allen, editors. 2014. Socialecological resilience and law. Columbia University Press, New York, New York, USA.

Garmestani, A. S., and M. H. Benson. 2013. A framework for resilience-based governance of social-ecological systems. Ecology and Society 18(1): 9. http://dx.doi.org/10.5751/ES-05180-180109

Gearty, C. 2004. Principles of human rights adjudication. Oxford University Press, Oxford, UK.

General Assembly of the United Nations. 1972. Report of the United Nations conference on the human environment (Stockholm, 5-16 June 1972). Declaration of the United Nations conference on the human environment. A/Conf.48/14/Rev. 1. United Nations, New York, New York, USA.

General Assembly of the United Nations. 1992. Report of the United Nations conference on environment and development (Rio de Janeiro, 3-14 June 1992). Annex I: Rio declaration on environment and development. A/CONF.151/26. United Nations, New York, New York, USA.
Greenpeace E.V. and Others v. Germany, (App. no. 18215/06) ECtHR admissibility hearing, 12 May 2009.

Greer, S. 2006. The European convention on human rights: achievements, problems and prospects. Cambridge University Press, Cambridge, UK. http://dx.doi.org/10.1017/CBO9780511494963

Guerra and Others v. Italy, (1998) 26 EHRR 357.

Gunderson, L. H., and S. S. Light. 2006. Adaptive management and adaptive governance in the Everglades ecosystem. Policy Sciences 39:323-334. http://dx.doi.org/10.1007/s11077-006-9027-2

Hahn, T., P. Olsson, C. Folke, and K. Johansson. 2006. Trustbuilding, knowledge generation and organizational innovations: the role of a bridging organization for adaptive comanagement of a wetland landscape around Kristianstad, Sweden. Human Ecology 34(4):573-592. http://dx.doi.org/10.1007/s10745-006-9035$\underline{\mathrm{Z}}$

Hajer, M. A., and H. Wagenaar. 2003. Deliberative policy analysis: understanding governance in the network society. Cambridge University Press, Cambridge, UK. http://dx.doi.org/10.1017/ CBO9780511490934

Hatton and Others v. the United Kingdom, (2003) 37 EHRR 28.

Hilson, C. 2013. The margin of appreciation, domestic irregularity and domestic court rulings in ECHR environmental jurisprudence: global legal pluralism in action. Global Constitutionalism 2(2):262-286. http://dx.doi.org/10.1017/ $\underline{\mathrm{S} 2045381713000075}$

Holling, C. S. 1978. Adaptive environmental assessment and management. Wiley, Chichester, UK.

Holling, C. S. 2012. Response to "Panarchy and the law." Ecology and Society 17(4): 37. http://dx.doi.org/10.5751/ES-05402-170437

Huitema, D., E. Mostert, W. Egas, S. Moellenkamp, C. PahlWostl, and R. Yalcin. 2009. Adaptive water governance: assessing the institutional prescriptions of adaptive (co-)management from a governance perspective and defining a research agenda. Ecology and Society 14(1): 26. [online] URL: http://www.ecologyandsociety. org/vol14/iss1/art26/

Hyam, J. 2003. Hatton v United Kingdom in the Grand Chamber: one step forward, to steps back. European Human Rights Law Review 8(6):631-640.

Jasanoff, S. 1997. Science at the bar: law, science, and technology in America. Harvard University Press, Cambridge, Massachusetts, USA.

Kennedy, D. 1997. A critique of adjudication. Harvard University Press, Cambridge, Massachusetts, USA.

Koskenniemi, M. 1999. The effect of rights on political culture. Pages 99-116 in P. Alston, editor. The EU and human rights. Oxford University Press, Oxford, UK.

Kyrtatos v. Greece, (2005) 40 EHRR 16.

Leach, M., I. Scoones, and A. Stirling. 2010. Dynamic sustainabilities: technology, environment, social justice. Earthscan, London, UK.

Ledyaeva Dobrokhotova, Zolotareva and Romashina v. Russia, (App. nos. 53157/99, 53247/99, and 56850/00) ECtHR, 26 October 2006. 
Letsas, G. 2004. The truth in autonomous concepts: how to interpret the ECHR. European Journal of International Law 15 (2):279-305. http://dx.doi.org/10.1093/ejil/15.2.279

\section{López Ostra v. Spain, (1994) 20 EHRR 277.}

Lundholm, C., and R. Plummer. 2010. Resilience and learning: a conspectus for environmental education. Environmental Education Research 16(5-6):475-491. http://dx.doi.org/10.1080/13504622.2010.505421

Merrills, J. G. 2007. Environmental rights. Pages 664-680 in D. Bodansky, J. Brunnée, and E. Hey, editors. The Oxford handbook of international environmental law. Oxford University Press, Oxford, UK. http://dx.doi.org/10.1093/oxfordhb/9780199552153.013.0028

O'Donnell, T. A. 1982. The margin of appreciation doctrine: standards in the jurisprudence of the European Court of Human Rights. Human Rights Quarterly 4:474-496. http://dx.doi. org/10.2307/762206

Olsson, P., L. H. Gunderson, S. R. Carpenter, P. Ryan, L. Lebel, C. Folke, and C. S. Holling. 2006. Shooting the rapids: navigating transitions to adaptive governance of social-ecological systems. Ecology and Society 11(1): 18. [online] URL: http://www. ecologyandsociety.org/vol11/iss1/art18/

Oneryildiz v. Turkey, (2004) 41 EHRR 20.

Ostrom, V. 1972. Polycentricity. The Vincent and Elinor Ostrom Workshop in Political Theory and Policy Analysis, Indiana University Bloomington, Bloomington, Indiana, USA.

Ostrom, E. 2010. Polycentric systems for coping with collective action and global environmental change. Global Environmental Change 20:550-557. http://dx.doi.org/10.1016/j.gloenvcha.2010.07.004

Parliamentary Assembly of the Council of Europe. 2003. Recommendation 1614. COE, Strasbourg, France.

Pathak, R. S. 1992. The human rights system as a conceptual framework for environmental law. Pages 205-243 in E. Brown Weiss, editor. Environmental change and international law: new challenges and directions. United Nations University Press, Tokyo, Japan.

Pedersen, O. W. 2008. European environmental human rights and environmental rights: a long time coming? Georgetown International Environmental Law Review 21:73-111.

Pedersen, O. W. 2010. The ties that bind: the environment, the European convention on human rights and the rule of law. European Public Law 16(4):571-595. http://dx.doi.org/10.2139/ $\underline{\text { ssrn. } 1673125}$

Powell \& Raynor v. United Kingdom, (1990) 12 EHRR 355.

Sadeghi, K. C. 2009. The European Court of Human Rights: the problematic nature of the court's reliance on secondary sources for fact-finding. Connecticut Journal of International Law 25:127-152.

Sands, P. 2003. Principles of international environmental law. Cambridge University Press, Cambridge, UK. http://dx.doi. org/10.1017/CBO9780511813511

Schachter, O. 1983. Human dignity as a normative concept. American Journal of International Law 77:848-854. http://dx.doi. org/10.2307/2202536

Shelton, D. 2006. Human rights and the environment: what specific environmental rights have been recognized? Denver Journal of International Law and Policy 35:129-172.
Shelton, D. 2010. Developing substantive environmental rights. Journal of Human Rights and the Environment 1(1):89-120. http:// dx.doi.org/10.4337/jhre.2010.01.05

Shigeta, Y. 2010. International judicial control of environmental protection: standard setting, compliance control and the development of international environmental law by the international judiciary. Kluwer Law International, Alphen aan den Rijn, the Netherlands.

Sohn, L. B. 1982. The new international law: protection of the rights of individuals rather than states. American University Law Review 32(1):1-64.

Stallworthy, M. 2005. Whither environmental human rights. Environmental Law Review 7:12-33. http://dx.doi.org/10.1350/ enlr.7.1.12.63573

Steiner, H. J., and P. Alston. 2000. International human rights in context: law politics morals. Second edition. Oxford University Press, Oxford, UK.

Taskin and Others v. Turkey, (2004) 42 EHRR 50.

Tatar v. Romania, (App. no. 67021/01) ECtHR, 27 January 2009.

Twining, W. 2009. General jurisprudence: understanding law from a global perspective. Cambridge University Press, Cambridge, UK. http://dx.doi.org/10.1017/CBO9780511807374

United Nations. United Nations convention on the law of the sea (Montego Bay, Jamaica, 10 December 1982). 1833 United Nations Treaty Series 3. United Nations, New York, New York, USA.

United Nations Economic Commission for Europe (UNECE). Convention on access to information, public participation in decisionmaking and access to justice in environmental matters (Aarhus, Denmark, 25 June 1998). ECE/CEP/43. UNECE, Geneva, Switzerland.

Voß, J.-P., D. Bauknecht, and R. Kemp, editors. 2006. Reflexive governance for sustainable development. Edward Elgar, Cheltenham, UK. http://dx.doi.org/10.4337/9781847200266

Walker, B. H. 2012. A commentary on "Resilience and water governance: adaptive governance in the Columbia River Basin." Ecology and Society 17(4): 29. http://dx.doi.org/10.5751/ ES-05422-170429

Walters, C. 1986. Adaptive management of renewable resources. Macmillan, New York, New York, USA.

West, S. 2011. Physical morality: how does the application of human rights norms to environment in the European Court of Human Rights challenge the environmental epistemology of, and affect the mobilisation of, scientific information within environmental law? Thesis. School of Oriental and African Studies, University of London, London, UK.

World Trade Organization (WTO). 1994. Agreement establishing the World Trade Organization (Marrakesh, 15 April 1994). 1867 United Nations Treaty Series 154. WTO, Geneva, Switzerland.

Young, K. 2008. The minimum core of economic and social rights: a concept in search of content. Yale Journal of International Law 33:113-175. 